Marquette University

e-Publications@Marquette

School of Dentistry Faculty Research and

Publications

Dentistry, School of

$10-1-2008$

\title{
Effect of Phosphate Group Addition on the Properties of Denture Base Resins
}

Gaurav Puri

Marquette University

David W. Berzins

Marquette University, david.berzins@marquette.edu

Virendra B. Dhuru

Marquette University, virendra.dhuru@marquette.edu

Periathamby A. Raj

Marquette University

Sameer K. Rambhia

Marquette University

See next page for additional authors

Accepted version. The Journal of Prosthetic Dentistry, Vol. 100, No. 4 (October 2008): 302-308. DOI. (C) 2008 Elsevier. Used with permission. 
Authors

Gaurav Puri, David W. Berzins, Virendra B. Dhuru, Periathamby A. Raj, Sameer K. Rambhia, Gunjan Dhir, and Andrew R. Dentino 


\title{
Effect of Phosphate Group Addition on the Properties of Denture Base Resins
}

\author{
Gaurav Puri \\ Private practice \\ Spokane, WA \\ David W. Berzins \\ Department of General Dental Sciences, Marquette University \\ School of Dentistry \\ Milwaukee, WI \\ Virendra B. Dhuru \\ Department of General Dental Sciences, Marquette University \\ School of Dentistry \\ Milwaukee, WI \\ Periathamby A. Raj \\ Chief Science Officer, PeriDent Therapeutics \\ North Andover, MA \\ Sameer K. Rambhia \\ Department of General Dental Sciences, Marquette University \\ School of Dentistry \\ Milwaukee, WI
}




\title{
Gunjan Dhir \\ Private practice \\ Spokane, WA
}

\author{
Andrew R. Dentino \\ Department of Surgical Sciences, Marquette University School of \\ Dentistry \\ Milwaukee, WI
}

\begin{abstract}
:
Statement of problem

Acrylic resins are prone to microbial adherence, especially by Candida albicans. Surface-charged resins alter the ionic interaction between the denture resin and Candida hyphae, and these resins are being developed as a means to reduce microbial colonization on the denture surface.
\end{abstract}

Purpose

The purpose of this study was to investigate the physical and mechanical properties of phosphate-containing polymethyl methacrylate resins for their suitability as a denture material.

\section{Material and methods}

Using PMMA with cross-linker (Lucitone 199) as a control, 4 experimental groups containing various levels of phosphate with and without cross-linker were generated. The properties examined were impact strength, fracture toughness, wettability (contact angle), and resin bonding ability to denture teeth. Impact strength was tested in the Izod configuration $(n=16)$, and fracture toughness $(n=13)$ was measured using the single-edge notched bend test. Wettability was determined by calculating the contact angle of water on the material surface $(n=12)$, while ISO 1567 was used for bonding ability $(n=12)$. The data were analyzed by 1 - and 2-way ANOVA $(a=.05)$. 
NOT THE PUBLISHED VERSION; this is the author's final, peer-reviewed manuscript. The published version may be accessed by following the link in the citation at the bottom of the page.

\section{Results}

A trend of increased hydrophilicity, as indicated by lower contact angle, was observed with increased concentrations of phosphate. With regard to the other properties, no significant differences were found when compared with the control acrylic resin.

\section{Conclusions}

No adverse physical effect due to the addition of a phosphatecontaining monomer was found in the acrylic denture resins. Additional mechanical and physical properties, biocompatibility, and clinical efficacy studies are needed to confirm the in vivo anti-Candida activity of these novel resins.

Acrylic resins have adequate physical, mechanical, and esthetic properties for use as denture base materials in the prosthetic rehabilitation of edentulous patients. However, their application is flawed by the ease of microbial adherence to the intaglio (tissue) surface of the denture base. Mechanical irritation by the prosthesis and decreased manual dexterity for oral hygiene by geriatric patients predispose the elderly edentulous population to denture stomatitis. ${ }^{1,2}$ Denture stomatitis itself is not the manifestation of systemic pathology, but is a result of local factors, such as ill-fitting dentures and biofilm formation on the prosthetic surface. The condition has not generally been considered serious, but does result in chronic inflammation and may act as a nidus of serious infection in the elderly or immune-compromised patients. ${ }^{3-4}$

The intaglio surface of the denture is not polished prior to insertion and the areas of imperfection, porosities, or rough areas in the denture may serve as a breeding ground for opportunistic oral fungi. ${ }^{5}$ The treatment for Candida infection in denture stomatitis is to remove the source of irritation and apply antifungal agents orally in the form of drops, lozenges, or mouthwashes. However, in vitro, it has been noted that planktonic Candida species are much more susceptible to antifungals than Candida contained in biofilms. Biofilm-associated Candida, as seen on a denture surface, is becoming increasingly more resistant to antifungal therapy. ${ }^{6-9}$ Therefore, it is prudent to evaluate alternative materials which may hinder Candida adherence. ${ }^{10-11}$

Journal of Prosthetic Dentistry, Vol. 100, No. 4 (October 2008): pg. 302-308. DOI. This article is (C) Elsevier and permission has been granted for this version to appear in e-Publications@Marquette. Elsevier does not grant permission for this article to be further copied/distributed or hosted elsewhere without the express permission from Elsevier. 
Differences exist in the protein composition of the acquired denture pellicle and enamel pellicle found on teeth. The acquired enamel pellicle consists of adsorbed salivary amylase, mucin, albumin, and other constituents such as cationic anti-microbial peptides. In contrast, the denture pellicle lacks salivary histatins and proline-rich proteins. ${ }^{12}$ The salivary histatins in the acquired enamel pellicle have been reported to have fungicidal properties. ${ }^{13-14}$ This difference in protein composition of the acquired denture pellicle and the enamel pellicle has been attributed to the absence of anionic groups, such as phosphate, in the acrylic resin. ${ }^{12}$ Therefore, the development of acrylic resins with negatively charged groups, either as a surface modification or throughout the resin, has the potential to hinder Candida adhesion, with inhibition being directly proportional to the extent of the negative charge in the polymer. ${ }^{10-11}$

Polymethyl methacrylate (PMMA) denture base resins are formulated from a liquid containing methyl methacrylate (MMA) monomer and a powder containing PMMA prepolymer. The incorporation of phosphate groups in PMMA provides the acrylic resin with an anionic surface charge which facilitates adsorption of salivary defense molecules such as histatins and defensins. Since charged acrylic resins have been shown to have a dose-related anti-Candida activity, ${ }^{10}$ optimization of this effect without compromising the physical properties of the denture base resins is desired. To date, flexural strength and modulus, water sorption and solubility, as well as color stability, have been examined. ${ }^{15}$

Adequate impact strength and fracture toughness are 2 of the most important mechanical property requirements of denture base resins. A denture that is accidentally dropped onto a hard surface may fracture if its impact strength, or resistance to fracture under dynamic load, is not sufficient. Similarly, the fracture toughness gives a measure of a material's resistance to crack propagation, a common source of failure in denture base resins. ${ }^{16}$ Wettability, as measured by contact angle of water on the material, is important in denture retention ${ }^{17}$ and provides an indication of the change in surface charge created by the addition of phosphate groups. Furthermore, hypdrophobic as well as electrostatic interactions are important to Candida adherence to surfaces, ${ }^{18-19}$ and Uyen et $\mathrm{al}^{20}$ has demonstrated that as hydrophilicity increases, bacterial binding also decreases. The

Journal of Prosthetic Dentistry, Vol. 100, No. 4 (October 2008): pg. 302-308. DOI. This article is @ Elsevier and permission has been granted for this version to appear in e-Publications@Marquette. Elsevier does not grant permission for this article to be further copied/distributed or hosted elsewhere without the express permission from Elsevier. 
bonding ability of the denture base resin to artificial teeth was also investigated in this study, since it is possible the phosphate modification may compromise the bond. The purpose of this study was to determine the effect of phosphate group substitution via incorporation of ethylene glycol methacrylate phosphate (EGMP) on 4 mechanical/physical properties of denture base resins. The properties investigated were impact strength, fracture toughness, wettability, and bonding ability to denture teeth. Therefore, the null hypothesis was that addition of a phosphate monomer to Lucitone 199 has no effect on the mechanical and physical properties under study.

\section{MATERIAL AND METHODS}

The materials used in this study are shown in Table I. A commercially available acrylic denture base resin, Lucitone 199 (Lot \# 0501121; Dentsply Trubyte, York, Pa), was used as the control and the basis for the 4 experimental groups. The manufacturer of Lucitone 199 purports that it consists of a powder (containing PMMA prepolymer, initiator, and other additives) and a liquid (containing MMA monomer and the cross-linking agent, ethylene glycol dimethacrylate (EGDMA)). For all groups, the manufacturer's instructions for Lucitone 199 with regard to standard packing, liquid: powder ratio $(3: 1)$, and polymerization cycle $\left(74^{\circ} \mathrm{C}\right.$ for 9 hours) were followed. The experimental groups (E-10, E-15, and E-20) were formulated with a phosphate-containing monomer, EGMP (Batch \# 15605AE; Sigma-Aldrich, St. Louis, Mo), substituted for the liquid MMA monomer in increasing concentrations of $10 \%, 15 \%$, and $20 \%$ by volume, respectively. A fourth experimental group $(E-15+X L)$ also had the cross-linking agent, EGDMA (Batch \#02108LC; Sigma-Aldrich), added to return the overall EGDMA concentration to $7.5 \%$ by volume. This was done to discern whether any change in mechanical properties was due to the added phosphate group containing monomer itself or because the experimental substitutions effectively diluted the other components of the liquid, such as the cross-linking agent. 
NOT THE PUBLISHED VERSION; this is the author's final, peer-reviewed manuscript. The published version may be accessed by following the link in the citation at the bottom of the page.

\begin{tabular}{ll}
\hline Group & Powder:Liquid Ratio \\
\hline L199 (Lucitone 199) & $3: 1$ \\
\hline E-10 & $3: 1$ with $10 \%$ by volume of EGMP substituted in liquid \\
\hline E-15 & $3: 1$ with $15 \%$ by volume of EGMP substituted in liquid \\
\hline E-15+XI (cross-linking agent) & $3: 1$ with $15 \%$ by volume of EGMP substituted in liquid and \\
& 7.5 wt $\%$ of cross-linking agent (EGDMA) \\
\hline E-20 & $3: 1$ with $20 \%$ by volume of EGMP substituted in liquid \\
\hline
\end{tabular}

Table I Denture base resins investigated

EGDMA = ethylene glycol dimethacrylate; EGMP = ethylene glycol methacrylate phosphate.

Impact strength specimens $(50 \times 6 \times 4 \mathrm{~mm} ; \mathrm{n}=16)$ for each group were machined from 2 larger polymerized plates $(65 \times 40 \times 5$ $\mathrm{mm})$. A notch was cut in accordance with ISO standard 180:2000 21 in the middle of the specimen to a depth of $1.2 \pm 0.1 \mathrm{~mm}$. The specimens were conditioned in water at $37 \pm 1^{\circ} \mathrm{C}$ for 7 days \pm 2 hours prior to testing. A 2 J Izod impact tester (Testing Machine, Inc, Ronkonkoma, $\mathrm{NY}$ ) was used to measure the impact energy required to fracture the specimen. The impact strength (IS) was calculated using the following formula ${ }^{21}$ :

$$
\mathrm{IS}=\mathrm{E}_{\mathrm{c}} /(\mathrm{hp})
$$

where $E_{c}$ is the corrected absorbed energy, $h$ is the specimen thickness, and $b$ is the width below the notch.

Fracture toughness was determined using the single-edge notched bend test. ${ }^{22}$ Specimens $(40 \times 8 \times 4 \mathrm{~mm} ; \mathrm{n}=13)$ for each group were machined from 2 larger polymerized plates $(65 \times 40 \times 5$ $\mathrm{mm}$ ). A $0.5-\mathrm{mm}$-wide notch, $3.6 \mathrm{~mm}$ in length, was machined in the center of each specimen and then sharpened using a razor blade to extend the notch another 0.1 to $0.2 \mathrm{~mm} .{ }^{22}$ The specimens were conditioned in water at $37 \pm 1^{\circ} \mathrm{C}$ for 7 days \pm 2 hours prior to testing. Fracture toughness measurements were performed in a 3-point bending configuration in a universal testing machine (Model 55R1114; Instron Corp, Canton, Mass) using a crosshead speed of $1 \mathrm{~mm} / \mathrm{min}$ 
and a support span of $32 \mathrm{~mm}$. The fracture toughness, $\mathrm{K}_{\mathrm{IC}}$, was calculated using the formula ${ }^{23}$ :

$$
\mathrm{K}_{\mathrm{IC}}=\mathrm{fLP}_{\max } /\left(B \mathrm{~W}^{1.5}\right)
$$

where $f$ is a factor depending upon the ratio of crack length to specimen width given in ASTM Standard E399-90, $P_{\max }$ is the maximum load, $\mathrm{L}$ is the distance between testing supports, $\mathrm{B}$ is the specimen thickness, and $\mathrm{W}$ is the specimen width. The work of fracture (WOF), which is defined as the energy needed to produce 2 fractured surfaces, ${ }^{24}$ was also calculated using the formula ${ }^{25}$ :

\section{$\mathrm{WOF}=\mathrm{U} /(2 \mathrm{~B}(\mathrm{~W}-\mathrm{a}))$}

where $a$ is the crack length and $U$ is the total work found by computing the area under the entire load-displacement curve.

Twelve specimens $(15 \times 15 \times 5 \mathrm{~mm})$ were examined for contact angle for each group. Six of the 12 specimens were cleaned and polished using pumice (coarse, fine, and extra fine), followed with sequential grinding with silicon carbide paper of 400,600, and 1200 grits (Buehler Ltd, Lake Bluff, III). The other 6 specimens were tested without any cleaning or polishing. This latter subgroup was designated as "unpolished" and represents the denture intaglio surface which does not undergo any alteration prior to insertion intraorally. The polished surfaces are more typical of contact angle specimen preparation, although further polishing with alumina slurry was not performed as it could potentially contaminate the experimental group surfaces. The contact angle of distilled water on the specimen surfaces was measured by the sessile drop method. For this, a 20- $\mu$ l drop was delivered from a microsyringe (Krüss USA, Matthews, NC) onto the surface of the horizontally leveled specimen. After 20 seconds of spreading time, the contact angle was determined by observing the drop profile with a drop shape analysis system and software (Krüss USA). The automated drop shape analysis system software calculates the angle between the solid and the tangent to the surface of the drop on the acquired optical image.

ISO standard $1567^{26}$ for denture base polymers was followed for testing the bond of acrylic resin denture teeth to the acrylic resins under investigation. Two specimen plates for each group were 
fabricated, each with 6 maxillary central incisors (Portrait IPN; Dentsply Trubyte). The teeth were arranged to allow the lingual surface of the incisal edge of each tooth to individually contact the debonding blade connected to the crosshead of the universal testing machine. The load was applied to the tooth at a crosshead speed of 2 $\mathrm{mm} / \mathrm{min}$ until failure occurred. Mode of bond failure was noted in accordance with the standard. ${ }^{26}$ The specimen passed if the mode of fracture was cohesive either within the denture tooth or the acrylic resin, but not if the tooth debonded from the acrylic resin.

Normality of the data was confirmed using the Shapiro-Wilk test. The data for impact strength and fracture toughness were analyzed using 1-way analysis of variance (ANOVA) and an additional post hoc Tukey test was performed when indicated (SPSS 13.0; SPSS, Inc, Chicago, III). Two-way ANOVA was used for analyzing the data from the contact angle tests. The level of significance was set at $a=.05$.

\section{RESULTS}

The mean and standard deviation values for Izod impact strength, fracture toughness, and work of fracture are reported in Table II. No significant difference $(F=1.367, d f=4,65$, and $P=.255)$ in impact strength was found between any groups. For fracture toughness, once again, the values for all groups were not statistically different $(F=1.218, d f=4,54$, and $P=.314)$. This is an indication that these important properties were not changed significantly with the amount of the phosphate group substituted into the polymer. The mean work of fracture values for $\mathrm{E}-10$ were significantly greater than some of the other groups $(\mathrm{F}=5.199, d f=4,54$ and $P=.001)$, but a consistent trend in work of fracture with regard to the addition of phosphate was not apparent. This also reiterates that mechanical properties were not changed with the addition of the experimental phosphate compound.

Journal of Prosthetic Dentistry, Vol. 100, No. 4 (October 2008): pg. 302-308. DOI. This article is (C Elsevier and permission has been granted for this version to appear in e-Publications@Marquette. Elsevier does not grant permission for this article to be further copied/distributed or hosted elsewhere without the express permission from Elsevier. 
NOT THE PUBLISHED VERSION; this is the author's final, peer-reviewed manuscript. The published version may be accessed by following the link in the citation at the bottom of the page.

\begin{tabular}{lccccc}
\hline $\begin{array}{l}\text { Property } \\
\text { (Units) }\end{array}$ & L199 & E-10 & E-15 & E-15+XL & E-20 \\
\hline $\begin{array}{l}\text { Izod impact } \\
\text { strength }\left(\mathrm{kJ} / \mathrm{m}^{2}\right)\end{array}$ & $4.56(0.32)^{\mathrm{A}}$ & $4.59(0.68)^{\mathrm{A}}$ & $4.52(0.46)^{\mathrm{A}}$ & $4.69(0.48)^{\mathrm{A}}$ & $4.28(0.51)^{\mathrm{A}}$ \\
$\begin{array}{l}\text { Fracture toughness, } \\
\text { KIC }\left(\mathrm{MPa} \cdot \mathrm{m}^{1 / 2}\right)\end{array}$ & $2.37(0.21)^{\mathrm{A}}$ & $2.39(0.23)^{\mathrm{A}}$ & $2.29(0.18)^{\mathrm{A}}$ & $2.34(0.22)^{\mathrm{A}}$ & $2.21(0.23)^{\mathrm{A}}$ \\
& & & & & \\
$\begin{array}{l}\text { Work of fracture } \\
\left(\mathrm{kJ} / \mathrm{m}^{2}\right)\end{array}$ & $0.99(0.30)^{\mathrm{B}}$ & $1.27(0.13)^{\mathrm{A}}$ & $1.15(0.17)^{\mathrm{AB}}$ & $1.04(0.18)^{\mathrm{AB}}$ & $0.94(0.18)^{\mathrm{B}}$ \\
\hline
\end{tabular}

Table II Mean (SD) mechanical properties evaluated

For each property, values with same uppercase letters were not statistically different $(P<.05$; 1-way ANOVA and post hoc Tukey test).

Table III displays the contact angles for the polished and unpolished specimens. For both preparation conditions, there was a general trend of decreasing contact angle with increase in the phosphate concentration. This would indicate greater hydrophilicity with phosphate addition. Two-way ANOVA and the Tukey test showed E-20 had a significantly $(P=.039)$ lower contact angle than the other groups (Table IV). Polished surfaces also had significantly $(P<.001)$ lower contact angles than the unpolished specimens. The interaction between group composition and surface condition was not significant $(P=.096)$. Despite this apparent change in surface properties, bonding ability of the acrylic resins to artificial teeth was not affected, since all groups showed cohesive fracture of the tooth, indicating no compromise of the bond between the experimental acrylic resin groups to artificial teeth. For this test, all groups passed the requirements of ISO 1567. 


\begin{tabular}{lcc}
\hline & \multicolumn{2}{c}{ Contact Angle } \\
\cline { 2 - 3 } Group & Polished ${ }^{*}$ & Unpolished \\
\hline L199 & $73.7(3.3)$ & $78.8(4.1)$ \\
E-10 & $71.3(2.5)$ & $76.0(3.4)$ \\
E-15 & $71.8(3.9)$ & $75.6(4.6)$ \\
E-15+XI & $68.7(2.9)$ & $76.9(2.9)$ \\
E-20- & $68.6(4.2)$ & $68.5(3.3)$ \\
\hline
\end{tabular}

Table III Mean (SD) for contact angle measurements

*Polished surfaces had significantly $(P<.001 ; 2$-way ANOVA) lower contact angles than unpolished specimens.

**E-20 had significantly ( $P=.039 ; 2$-way ANOVA and post hoc Tukey test) lower contact angle than other groups.

\begin{tabular}{|c|c|c|c|c|c|}
\hline Source & df & $\begin{array}{l}\text { Sum of } \\
\text { Squares }\end{array}$ & $\begin{array}{l}\text { Mean } \\
\text { Square }\end{array}$ & $\mathbf{F}$ & $\mathbf{P}$ \\
\hline Corrected model & 9 & 772 & 85.8 & 6.8 & $<001$ \\
\hline Intercept & 1 & 319599 & 319599 & 25245 & $<001$ \\
\hline Group composition & 4 & 383 & 95.7 & 7.6 & $<001$ \\
\hline Surface condition & 1 & 283 & 283.1 & 22.4 & $<001$ \\
\hline Group composition ${ }^{\times}$surface condition & 4 & 106 & 26.5 & 2.1 & .096 \\
\hline Error & 50 & 633 & 12.7 & & \\
\hline Total & 60 & 321004 & & & \\
\hline Corrected total & 59 & 1405 & & & \\
\hline
\end{tabular}

TABLE IV Results of 2-way ANOVA with independent variables of group composition and surface condition, and contact angle as dependent variable.

Journal of Prosthetic Dentistry, Vol. 100, No. 4 (October 2008): pg. 302-308. DOI. This article is @ Elsevier and permission has been granted for this version to appear in e-Publications@Marquette. Elsevier does not grant permission for this article to be further copied/distributed or hosted elsewhere without the express permission from Elsevier. 
NOT THE PUBLISHED VERSION; this is the author's final, peer-reviewed manuscript. The published version may be accessed by following the link in the citation at the bottom of the page.

\section{DISCUSSION}

Altering a material to optimize a single property may consequentially introduce deleterious effects on other properties. However, in this study, addition of increasing amounts of EGMP to the denture base material did not result in a significant change in impact strength, fracture toughness, or bonding ability to artificial teeth compared to the control. As expected, the wettability measurement was significantly different for the E-20 group. Therefore, the null hypothesis is not rejected for the parameters tested, with the exception of the contact angle measurement at the highest level of phosphate substitution.

Impact strength is an important parameter, as it can reflect the contact force required to cause fracture in a denture under situations such as accidental dropping. Comparison with a previous investigation ${ }^{25}$ showed greater Izod impact strength values for Lucitone 199 in the present study $\left(4.56\right.$ versus $\left.2.85 \mathrm{~kJ} / \mathrm{m}^{2}\right)$. While the values are within a factor of 2 , the difference in results may be due to impact strength not being an intrinsic property and influenced by testing configuration and specimen geometry. ${ }^{25}$ The absolute values are most useful for intrastudy material comparisons, and, in this case, there were no significant differences in impact strength between Lucitone 199 and the experimental acrylic resins. Fracture toughness is also a critical property, as crack propagation is a common mode of failure for dentures. The values reported in the present study for $\mathrm{K}_{\mathrm{IC}}$ and $\operatorname{WOF}\left(2.37 \mathrm{MPa} \cdot \mathrm{m}^{1 / 2}\right.$ and $0.99 \mathrm{~kJ} / \mathrm{m}^{2}$, respectively) were similar to those $\left(2.53 \mathrm{MPa} \cdot \mathrm{m}^{1 / 2}\right.$ and $1.41 \mathrm{~kJ} / \mathrm{m}^{2}$, respectively) reported for Lucitone 199. ${ }^{25}$ Furthermore, the experimental acrylic resins were statistically similar to the control in $\mathrm{K}_{\mathrm{IC}}$ and WOF as a whole, indicating the phosphate addition did not substantially alter these measurements. Coupled with the fact that bonding to artificial teeth was not compromised, these experimental acrylic resins have proven to be relatively unaffected in the mechanical properties tested by the addition of the phosphate group.

The contact angle values obtained for the control (73.3 degrees) were consistent with those reported in the literature for Lucitone 199. ${ }^{17}$ With regard to the experimental acrylic resins, incorporation of a phosphate-containing monomer in place of MMA monomer in the liquid tended to increase the wettability, as indicated by decreasing 
contact angle. In other words, there was an overall decrease in hydrophobicity with increasing concentration of the phosphate compound. This is significant, as Klotz et al ${ }^{18}$ found that the increased adherence of yeasts to acrylic resins was directly proportional to an increase in hydrophobicity. These results are in agreement with the work done by Park et al. ${ }^{10-11}$ The authors suggested increasing the hydrophilicity of surface-modified resins as a possible mechanism for decreasing Candida adhesion to the polymer, since the hydrophobic Candida would be more readily attracted to hydrophobic denture base polymers. ${ }^{19}$ The observation that the polished specimens appear to have lower contact angles than the unpolished specimens may be due to either a surface energy or surface roughness effect. Grinding the surface, as done with the polished group, most likely increased the surface energy, resulting in lower contact angles compared to the natural surface of the unpolished group. In addition, it is well established that denture base resins with increased roughness, such as the unpolished group, will exhibit greater contact angles. ${ }^{17}$ With both surface conditions, polished and unpolished, the E-20 specimens exhibited significantly lower contact angles $(P=.039)$, although it should be noted that the former group is less relevant clinically, as the intaglio surface of a denture, the site of Candida colonization, is not polished.

Although the results presented here are encouraging, there are limitations to this study and further testing of properties is warranted. The lack of a statistically significant difference in the mechanical properties tested does not prove equivalence, but does suggest proof of the concept that phosphate can be added without adverse effects on these particular properties. It also suggests that clinically relevant changes have not occurred based on comparison to a widely used denture base material. Increased hydrophilicity did result in increased water sorption by the denture material, possibly resulting in dimensional changes and color instability. ${ }^{15}$ However, color stability was within ISO standards for each specimen tested, up to $20 \%$ phosphate, and water sorption as well as flexural strength and modulus were within international specification limits up to $10 \%$ phosphate, and this observation was conducted under decreasing cross-linker concentrations, a factor which is known to affect both properties. ${ }^{15}$ Additionally, while Candida colonization has been shown to be hindered on surface-charged resins, ${ }^{10-11}$ it is possible, and 
perhaps likely, that other organisms may be attracted to the more hydrophilic surface. ${ }^{20}$ Similarly, the incorporation of phosphate into the denture base material may provide a site for calcium mineralization to occur, which could present a problem for denture hygiene. Ultimately, the in vivo performance of the experimental acrylic resins must be considered.

\section{CONCLUSIONS}

Within the limitations of this study, it can be concluded that the incorporation of phosphate into an acrylic resin denture material by monomer substitution does not adversely affect its impact strength, fracture toughness, and bonding ability to artificial teeth. This process may be further explored to develop a clinically useful denture base that resists fungal colonization.

\section{Acknowledgements}

The authors thank COL Geoffrey Thompson and the US Army Dental and Trauma Research Detachment, Great Lakes, Ill, for use of the Izod impact tester. The authors are also grateful to Dr David Charlton, Dr Amer Tiba, and CAPT Dale Ehrlich of the Naval Institute for Dental and Biomedical Research, Great Lakes, Ill, for use of the drop shape analysis system.

This investigation was supported by the Greater New York Academy of Prosthodontics Student Grant Program, 2005, and NIDCR Grant \#DE016925.

\section{REFERENCES}

1. Budtz-Jörgensen E. Clinical aspects of Candida infection in denture wearers. J Am Dent Assoc. 1978;96:474-9.

2. Webb BC, Thomas CJ, Willcox MD, Harty DW, Knox KW. Candidaassociated denture stomatitis. Aetiology and management: a review. Part 2. Oral diseases caused by Candida species. Aust Dent J. $1998 ; 43: 160-6$.

3. Yoneyama T, Yoshida M, Ohrui T, Mukaiyama H, Okamoto H, Hoshiba K, et al. Oral care reduces pneumonia in older patients in nursing homes. J Am Geriatric Soc. 2002;50:430-3.

Journal of Prosthetic Dentistry, Vol. 100, No. 4 (October 2008): pg. 302-308. DOI. This article is (C Elsevier and permission has been granted for this version to appear in e-Publications@Marquette. Elsevier does not grant permission for this article to be further copied/distributed or hosted elsewhere without the express permission from Elsevier. 
NOT THE PUBLISHED VERSION; this is the author's final, peer-reviewed manuscript. The published version may be accessed by following the link in the citation at the bottom of the page.

4. Sumi Y, Miura M, Sunakawa M, Michiwaki Y, Sakagami N. Colonization of denture plaque by respiratory pathogens in dependent elderly. Gerodontology. 2002;19:25-9.

5. Ramage G, Tomsett K, Wickes BL, López-Ribot JL, Redding SW. Denture stomatitis: a role for Candida biofilms. Oral Surg Oral Med Oral Pathol Oral Radiol Endod. 2004;98:53-9.

6. Chandra J, Mukherjee PK, Leidich SD, Faddoul FF, Hoyer LL, Douglass LJ, et al. Antifungal resistance of candidal biofilms formed on denture acrylic in vitro. J Dent Res. 2001;80:903-8.

7. Kuhn DM, George T, Chandra J, Mukherjee PK, Ghannoum MA. Antifungal susceptibility of Candida biofilms: unique efficacy of amphotericin B lipid formulations and echinocandins. Antimicrob Agents Chemother. 2002; 46:1773-80.

8. Bachmann SP, Ramage G, VandeWalle K, Patterson TF, Wickes BL, LópezRibot JL1. Antifungal combinations against Candida albicans biofilms in vitro. Antimicrob Agents Chemother. 2003;47:3657-9.

9. Lamfon H, Porter SR, McCullough M, Pratten J. Susceptibility of Candida albicans biofilms grown in a constant depth film fermentor to chlorhexidine, fluconazole and miconazole: a longitudinal study. J Antimicrob Chemother. 2004;53:383-5.

10. Park SE, Periathamby AR, Loza JC. Effect of surface-charged poly(methyl methacrylate) on the adhesion of Candida albicans. J Prosthodont. $2003 ; 12: 249-54$.

11. Park SE, Blissett R, Susarla SM, Weber HP. Candida albicans adherence to surface-modified denture resin surfaces. J Prosthodont. 2008 Feb 5; Epub ahead of print.

12. Edgerton $M$, Levine $M J$. Characterization of acquired denture pellicle from healthy and stomatitis patients. J Prosthet Dent. 1992;68:683-91.

13. Raj PA, Edgerton M, Levine MJ. Salivary histatin 5: dependence of sequence, chain length and helical conformation for candidacidal activity. J Biol Chem. 1990;265:3898-905.

14. Baev D, Li XS, Dong J, Keng P, Edgerton M. Human salivary histatin 5 causes disordered volume regulation and cell cycle arrest in Candida albicans. Infect Immun. 2002;70:4777-84.

15. Dhir G, Berzins DW, Dhuru VB, Periathamby AR, Dentino A. Physical properties of denture base resins potentially resistant to Candida adhesion. J Prosthodont. 2007;16:465-72.

Journal of Prosthetic Dentistry, Vol. 100, No. 4 (October 2008): pg. 302-308. DOI. This article is @ Elsevier and permission has been granted for this version to appear in e-Publications@Marquette. Elsevier does not grant permission for this article to be further copied/distributed or hosted elsewhere without the express permission from Elsevier. 
NOT THE PUBLISHED VERSION; this is the author's final, peer-reviewed manuscript. The published version may be accessed by following the link in the citation at the bottom of the page.

16. Beyli MS, von Fraunhofer JA. An analysis of causes of fracture of acrylic resin dentures. J Prosthet Dent. 1981;46:238-41.

17. Monsénégo PH, Baszkin A, Costa ML, Lejoyeux J. Complete denture retention. Part II: Wettability studies on various acrylic resin denture base materials. J Prosthet Dent. 1989;62:308-12.

18. Klotz SA, Drutz DJ, Zajic JE. Factors governing adherence of Candida species to plastic surfaces. Infect Immun. 1985;50:97-101.

19. Klotz SA. The contribution of electrostatic forces to the process of adherence of Candida albicans yeast cells to substrates. FEMS Microbiol Lett. 1994;120:257-62.

20. Uyen HM, van der Mei HC, Weerkamp AH, Busscher HJ. Zeta potential and the adhesion of oral streptococci to polymethylmethacrylate. Biomat Artif Cells Artif Organs. 1989;17:385-91.

21. ISO 180:2000 . Plastics -- Determination of Izod impact strength. 3rd ed. International Organization for Standardization; Geneva: 2000. Available at: http://www.iso.ch/iso/en/prodsservices/ISOstore/store.html.

22. Williams JG, Cawood MJ. European group on fracture: Kc and Gc methods for polymers. Polymer Testing. 1990;9:15-26.

23. ASTM Standard E399-90 . 1990 Annual book of ASTM standards. ASTM; West Conshohocken: 1990. Standard test method for plane-strain fracture toughness of metallic materials; pp. 13-5.

24. Behr M, Rosentritt M, Faltermeier A, Handel G. Electron beam irradiation of denture base materials. J Mater Sci Mater Med. 2005;16:175-81.

25. Zappini G, Kammann A, Wachter W. Comparison of fracture tests of denture base materials. J Prosthet Dent. 2003;90:578-85

26. ISO 1567:1999 . Dentistry -- Denture base polymers. International Organization for Standardization; Geneva: 1999. Available at: http://www.iso.ch/iso/en/prods-services/ISOstore/store.html.

\section{About the Authors}

Andrew Dentino : Marquette University 1801 W. Wisconsin Ave Milwaukee, WI 53233

Fax: 414-288-8392

E-mail: andrew.dentino@marquette.edu

Journal of Prosthetic Dentistry, Vol. 100, No. 4 (October 2008): pg. 302-308. DOI. This article is (C Elsevier and permission has been granted for this version to appear in e-Publications@Marquette. Elsevier does not grant permission for this article to be further copied/distributed or hosted elsewhere without the express permission from Elsevier. 